\title{
ストック・フロー構造の把握による中山間地域の持続可能性検討フレ一ム*
}

\section{An Analysis Framework Applying “Stock-Flow Model” for Examination of Sustainability of Hilly and Mountainous Area*}

\author{
宮田将門 $*^{2} \cdot$ 戸上昭司 $*^{3} \cdot$ 加藤博和 $*^{4} \cdot$ 川瀬康博 $*^{5} \cdot$ 林良嗣 $*^{6}$ \\ By Masato MIYATA $*^{2} \cdot$ Shoji TOGAMI* $*^{3} \cdot$ Hirokazu KATO** $\cdot$ Yasuhiro KAWASE* ${ }^{5} \cdot$ Yoshitsugu HAYASHI $^{*^{6}}$
}

\section{1.はじめに}

戦後日本の国土政策のキーワードであり続けた「国土 の均衡ある発展」は、経済成長と人口増加を前提とした ものであり、都市地域での経済活動を原資とした所得移 転や公共事業が中山間地域を下支えする構造によって支 えられてきた。しかし、日本は 2005 年を境に総人口が 減少に転じ、少子高齢化も進んでいる。その結果、従来 の構造では下支えが困難となりつつある中山間地域につ いて、その必要性・存在意義や、自立的な維持発展のあ り方を再検討し、その結果を踏まえた新たな施策を実施 することが重要な課題となっている。

日本の国土構造変化は、都市化とともに進展した産業 構造変化と符合する。すなわち、農林業の衰退が都市以 外の地域を大きく変化させてきた。農林水産省において 規定された日本の農業地域類型区分は、都市的地域、平 地農業地域、中間農業地域、山間農業地域（後半2地域 を合わせて中山間地域と呼ぶ）の4つである。平地農業 地域の多くは都市郊外部に相当し、無秩序なスプロール 開発が問題となる地域であるが、都市化の進展が及んだ ことによって人口減少に陥らなかったという側面もある。 また傾斜が緩く区画が大規模であることから、近年徐々 にではあるが農業が復興の兆しを見せている。一方で、 耕地率が $20 \%$ 未満、森林率 $50 \%$ 以上と定義される中山間 地域においては人口減少・少子高齢化が著しく、限界集 落 ${ }^{1} ＼mathrm{~ （ 65 歳 以 上 人 口 比 50 \% 以 上 て ゙ あ る 地 域 ） も 多 く 見 ら ~}$ れる。国土交通省の報告2)では、10年以内の近い将来に 消滅する集落数が423箇所に上ると予測され、中山間地 域の衰退がいよいよ本格化する局面にある。

*キーワーズ : 地域計画、地区計画、土地利用

*2学生員、修 (工) 、名古屋大学大学院 環境学研究科

(名古屋市千種区不老町C1-2 (651)、TEL:052-789-3828、

E-mail:miyata@urban. env. nagoya-u. ac. jp)

*3非会員、修 (理) 、有限責任事業組合サステナブル経営 研究会

$*^{4}$ 正員、博 (工) 、名古屋大学大学院 環境学研究科

*5 非会員、（社）中部経済連合会 調查部

$*^{6}$ フェロー、工博、名古屋大学大学院 環境学研究科
このような、中山間地域が疲弊した過程を分析すると ともに、それが再生し持続可能となるための施策の方向 性を考えるためのフレームとして、本研究では、日本の 中山間地域が有するストックとそれに伴い都市地域との 間に発生するインフロー・アウトフローとの関係を表現 する枠組みを提案する。この枠組みを用いて、実際の中 山間地域の集落について、その付加価值や存在価值を分 析し、人口減少時代における持続可能性向上方策を検討 する方法を示すことを目的とする。

\section{2. ストック・フロ一把握フレームと中山間地域・都市 地域の再定義}

前述したように、日本において中山間地域とは、農 業地域区分によって定義される。農林水産省によると、 中山間地域は国土面積の 7 割、森林面積の 8 割、耕地面 積の 4 割、総農家数の 4 割、農業集落数の 5 割を占める。 また、中山間地域と対にして扱う都市地域は、国土利用 計画法の「都市地域」、あるいは都市計画法の「市街化 区域」、「市街化調整区域」、「市街化区域及び市街化 調整区域に関する都市計画が定められていない都市計画 区域における用途地域」を指寸。しかし、本研究では、 中山間地域と都市地域をそれぞれ、ストックとフローの 観点から再定義する。

\section{（1）日本の都市地域・中山間地域における} ストックの把握

経済学はストックを、1) 自然（土地）、2) 労働、3) 資本という生産の 3 要素という形でとらえる。アメリカ IE 協会の Industrial Engineering は、1)人、2)設備、 3)材料の 3 要素からなるとしている。これらの定義では、 資本や設備・材料が人工的であるか㧵かの区分はない。 一方、Dasgupta ${ }^{3)}$ は、経済の生産的基盤をその諸制度と 資本基盤とに分割して捉えることが最善であるとして、 資本基盤を、1）人工資本、2) 人的資本、3) 知識、4) 自然 資本の 4 つに区分している。 Meadows ${ }^{4)}$ は 1) Well-being、 2)Human capital \& social capital、3)Built capital \& human capital、4) Natural capital という 4 つに区 
分した上で、自然環境を考慮した上で資本を捉えるべき としている。宇沢 ${ }^{5)}$ も同様に、社会共通資本という概 念の中で、1) 自然環境、2)社会的インフラストラクチャ 一、3)制度資本の 3 つを挙げ、これらを持続的、安定的 に維持することで人間的に魅力ある社会が構築可能であ るとしている。

さらに、自然環境と中山間地域との関連について論 じた研究として、大野 ${ }^{2)}$ は、現代山村においては、水 田・畑・山林の地域資源をいかに管理していくかが環境 問題とあいまって鋭く問われると述べている。祖田 ${ }^{6)}$ は地方の地場産業について、地域資源の最大限利用を図 ることが、振興につながるとしている。ここでの地域資 源とは坂本ら ${ }^{7)}$ の定義を用い、1）天然資源、2)文化資 源、3) 人的資源の 3 つとしている。

以上に示した定義では、ストックを自然資本と人工資 本の 2 つ区分している。しかし害際には、それらの間 に、自然資源を人間が改良した半自然資源が存在する。 人工林や棚田は一見自然資本に見えるが、これらは人間 がより効率的に林業・農業を行うため、或いはそもそも それらの産業が不適合である地域に人が入り込んだため にできたものである。これが半自然資本と呼ぶゆえんで ある。これらは自然資本のようにメインテナンスフリー でもなく、一方で人工インフラのように供用期間が定め られたものでもなく、適切な維持管理をすることで半永 久的に機能寸ると考えられる。また、半自然資本は、農 産物や木材などの直接的な収穫はもとより、二酸化炭素 の吸収や水源涵養機能などの多面的機能をももたらして おり、日本学術会議 ${ }^{8)}$ において、農業では 1) 持続的食 料供給が国民に与える将来に対する安心、2)農業的土地 利用が物質循環系を補完することによる環境への貢献、

3)生産・生活空間の一体性と地域社会の形成・維持があ げられ、森林では 1) 生物多様性保全、2)地球環境保全、 3) 土砂災害防止/土壌保全、4) 水源涵養、5) 快適環境形 成、6)保健・レクリエーション、7) 文化といった多面的 機能があげられている。ただし、多面的機能の多くは市 場で取引されないため、半自然資本を維持することに対 して十分な対価が支払われないことに注意が必要である。
半自然資本は人の手が入ってはじめて維持されうる資本 のため、維持が滞れば農産物や木材などの直接的な収穫 が得られなくなるのみならず、多面的機能の低下を招き、 資本としての様々な価值を失うこととなる。

このように定義される半自然資本は、多くが中山間 地域に存在し、都市地域にはあまり存在しない。このこ とから、中山間地域と都市地域はそれぞれ図-1 のよう な資本の重層構造を有するとモデル化することができる。 中山間地域内のストックは、表-1 のように、1) 知識・ 技術（その地域特有の）、2) 人的資本、3) 人工資本、4) 半自然資本、5) 自然資本の 5 つからなる。一方、都市地 域には 4)・5）はほとんど存在しない（公園緑地は 4)に 分類されるが、直接的な収穫を得ることを目的としない 点で、中山間地域のそれと異なる）。これが本研究にお ける両地域の新たな定義である。
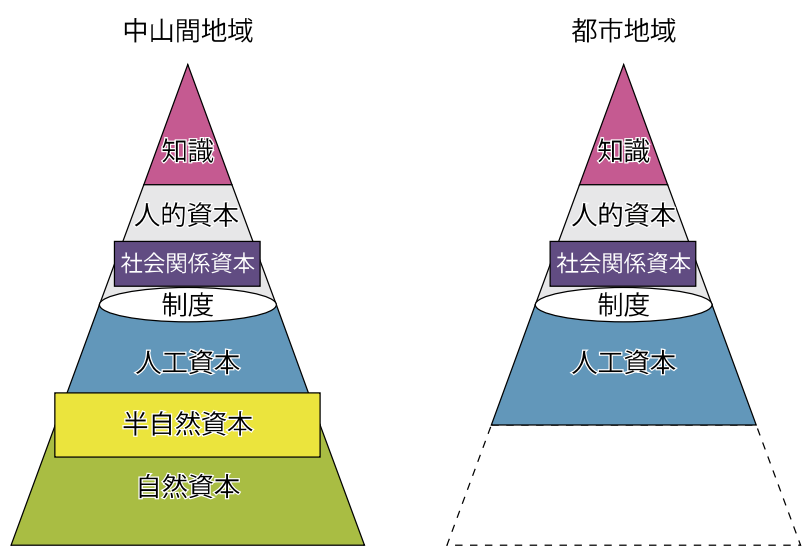

図-1 中山間地域と都市ストックの差異と階層化

（2）日本の都市地域・中山間地域における フローの把握

次に、各ストックにインフロー・アウトフローがどの ように関わっているかを把握する。

インフローとはその地域のストックの維持管理のた めに地域に投入されるフローである。アウトフローとは その地域が発生する、ストックの消費・活用および自然 との関わりによって人が享受できる生活の質（QOL）の

表-1 中山間地域の集落が有するストックの一覧

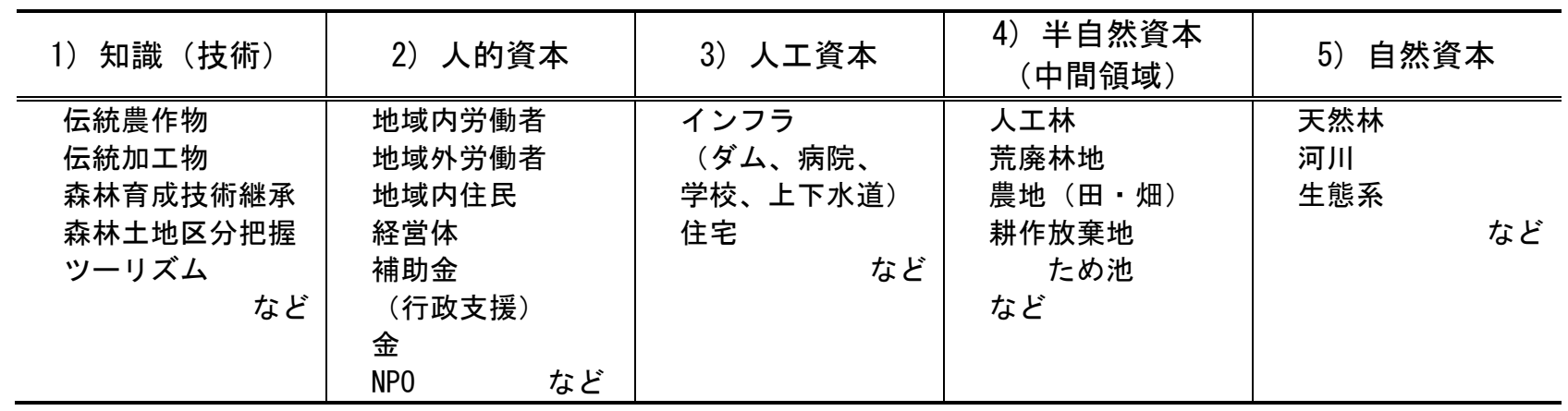


維持・向上に資するフローとして捉えることができる。 アウトフローの中には、森林・農地等の持つ多面的機能 が、都市地域を含む国土に便益をもたらすフローも把握 する必要がある。

フローが絶えず循環し続け、ストックが適切なバラ ンス・量を維持することで、その地域は社会的に持続可 能となる。ここで持続可能とは、ブルントラント委員会 9) の示す「将来世代の二ーズを損なうことなく現在の世 代のニーズを満たすこと」という定義を踏まえ、ストッ クの枯渇を招くことなく、将来世代のライフスタイルの 多様化に対応した住民の QOL の確保や環境負荷削減を可 能とするフローを作り出すことととらえる。

（3）ストック・フローの変遷

図-2 は、中山間地域と都市地域のストック・フロー の変遷を単純化して表示したものである。

江戸時代、中山間地域と都市地域との間には、それぞ れの土地で不足している物質・生産物の往来があり、互 いを補完し合う循環型社会が成立していた。中山間地域 から都市地域への人口（労働者）移動も少なく、それぞ れ地域内での労働によって生活が成り立っていた。また、 鎖国政策によって、海外との取引はごく限られた地域の みであった。すなわち、両地域のストックおよびそれに 基づくインフロー・アウトフローの量が一定に保たれた 結果、持続可能な営みが可能であったと考えられる。

産業革命以降、都市地域での工業化が進み、それに伴
い中山間地域の人口が徐々に都市地域での労働力となり、 同時に中山間地域の土地資源で生み出される木材や農作 物などが、人口が増加しつつある都市地域へのアウトフ ローとなった。それをもとに中山間地域は収入としてイ ンフローを得るという関係が構築された。この時代が中 山間地域から都市地域に向けてのアウトフローが最も多 かった時期である。

しかし、高度経済成長期に入ると、産業構造が第一次 から第二・第三次産業へ移行を始め、中山間地域の人口 流出は加速し労働力ストックは激减した。さらに、都市 地域と海外との関係が強くなり、都市地域のインフロ 一・アウトフローは海外との関係によって成り立ち、ス トックを増加させた。中山間地域はストックが豊富にあ りながらも、価格競争に敗れ、インフロー・アウトフロ 一ともに減少の一途を辿った。資金や人材の不足によっ て、ストックを適切に維持管理できなくなり、中山間地 域は都市地域からの補助などによってからうじて維持さ れ、特に半自然資本がもたらす、市場で取引されない多 面的機能の低下を招いた。現在では日本の中山間地域は、 かつての都市地域と補完し合う関係は見る影もない。ス トックが豊富にあったにも関わらず維持管理ができない ためにストックの質・価值が下がり、過度なインフロー の一方、アウトフローは微量に過ぎない。現代の日本に おいて日本の都市地域と補完的関係を有するのは海外な のである。

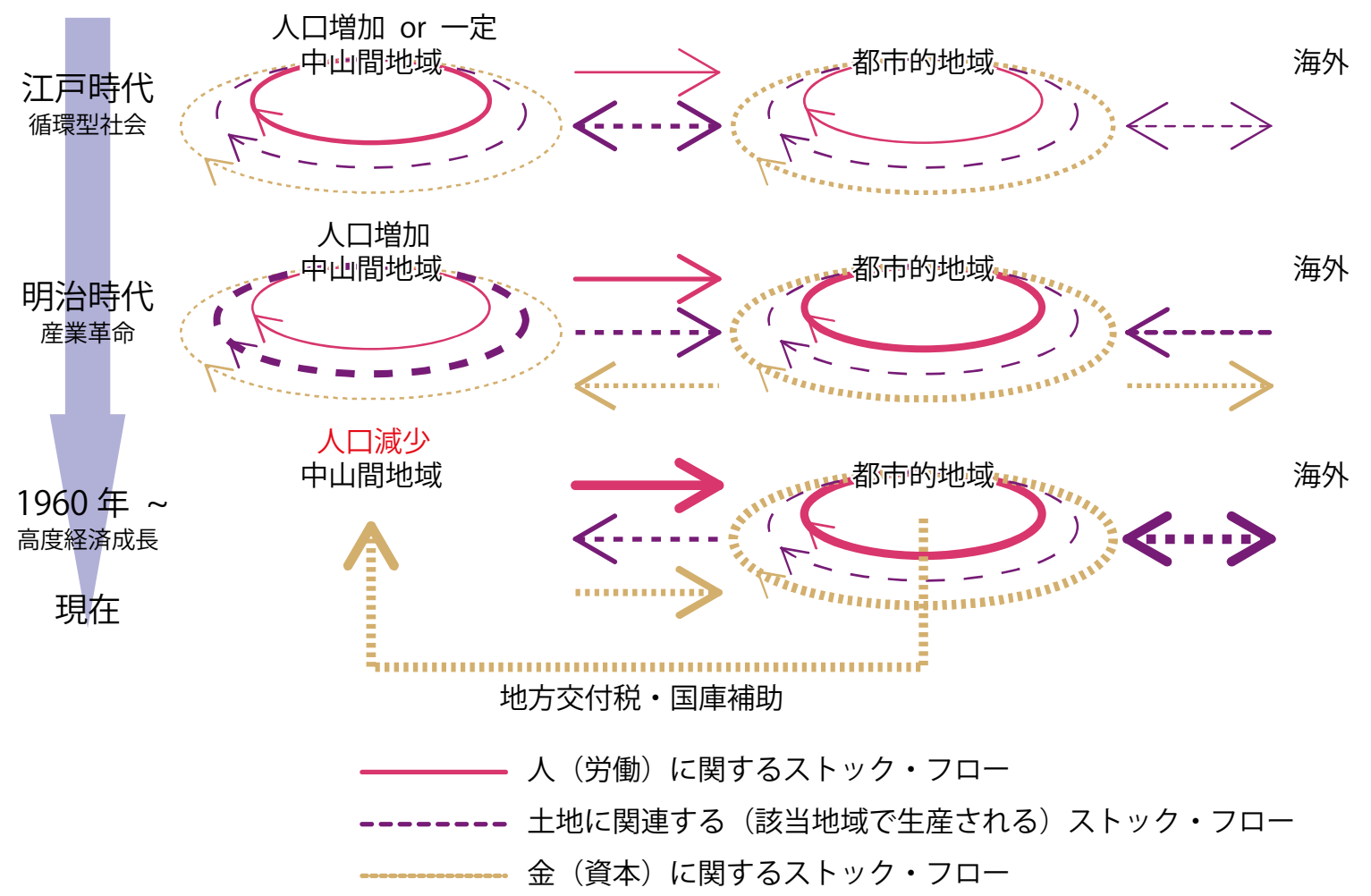

図-2 中山間地域の集落をめぐるストック・フローの変遷 


\section{3. 中山間地域の衰退状況の把握}

以上のフレームによって、中山間地域の定住人口減少 や高齢化などに伴う地域の活力低下について表面的に論 じるのでなく、地域のストックを把握し、それがいかな るポテンシャルを秘めているかを明らかにすることで、 いかにストックを活かしてフローを作り上げるかという 点から分析することが可能となる。

（1）産業衰退の構造

産業は、ストックをアウトフローに変える活動であ り、自立した中山間地域を構築するために欠かせないも のである。中山間地域における主要な産業は農林業と建 設業である。このうち、農林業は地域の半自然資本スト ックに立脚するものであるが、戦後一貫して衰退を続け てきた。その構造と関連する諸問題は図-3のようにまと めることができる。一方、建設業は、都市地域からの資 金のインフローを前提にするもので、それが利用され地 域活動が活発化することでアウトフローにも結びつくと いうものである。しかし、公共事業抑制によって建設業 も不振が続いている。また、事業の結果生まれたインフ ラ等が地域の活性化に十分結びつかない例も多い。抜本 的な構造改革がない限り、今後も中山間地域の衰退は確 実といえる。

（2）雇用環境の悪化

中山間地域では、第一次産業から第二・三次産業への 産業構造転換によって中山間地域が有しているストック の価值が低下している。そのために、農家の若者が、安 定して高い収入が得られる第二・三次産業への就労や、 そのための高等教育を望むことによって、近隣に都市地 域を持たない中山間地域では人口流出は避けられなかっ
た。例えば作野(10) は、島根県川本町を対象に衰退過程 を分析し、国関係の現業機関を中心とした官公署の著し い規模縮小が地域経済の衰退を招き、また企業誘致も進 まなかったため、雇用の場がきわめて限定されたことが 大きな要因になったと述べている。さらに作野11) は島 根県木次町（現・雲南市）を調査した結果、町内に企業 があり、通学できる距離に大学があるために人口流出が 阻止されたと述べている。

\section{（3）農林業における将来の可能性}

ところが近年では、農地・森林のストックは、多面的 なアウトフローを生み出す機能を有し、環境問題等の視 点から重要な役割を持っていると考えられるようになっ た。日本学術会議 ${ }^{8)}$ は、森林の多面的な機能を貨幣評 価した結果、約 70 兆円の価值があるとしている。日本 の森林の $41.2 \%$ 少人の手が入ってはじめて維持が可能な 人工林であり、その大半が中山間地域にあることを考え ると、中山間地域を消滅させることで、森林が有する多 面的機能をもたらすストックが劣化すれば、社会的にも 大きな損失を生み出す。

荒廃が進む中山間地域の森林を維持寸るためには、不 足している林業従事者を増加させ、適切な維持管理（間 伐など）を確保することが必要とされる。さらに近年で は輸入木材との価格差も僅差であることから、緑の循環 森林認証制度（SGEC）や森林管理協議会（FSC）などの 森林認証制度による木材のブランド化、維持管理のため の説明責任の明確化の取り組みが始まるなど、国内産木 材が見直されつつあり、今後の林業の復興も望める。

一方、農業については、減反と土地改良という相反す る政策が行われる中で国際競争力が低下し、2007年では 食料自給率が39\%になっている。食料安全保障の観点か ら農地の維持・再生が注目されつつある中、農地法の

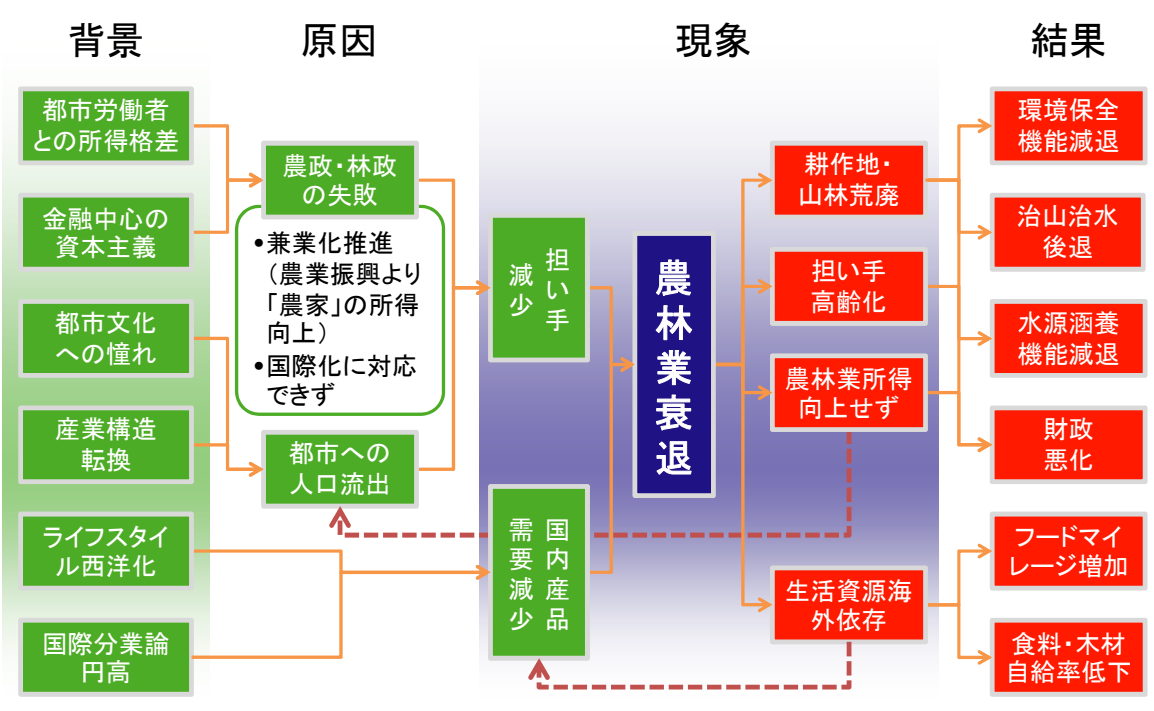

図-3 農林業衰退のメカニズムと諸問題 
改正に伴い、農地の貸借についての要件が緩和され、家 族経営や農業生産法人でなくとも農地を借りることが可 能となった。この結果、農業の生産性向上が見込まれる。 また、農業体験を観光として捉える動きも浸透しつつあ る。中山間地域では農業の生産性向上に限界がある一方、 棚田の水源涵養や治山治水に関する効果と、観光型農業 の需要の高まりが見られる。耕作放棄地復興についての 補助などが今後強化されれば、この動きが更に喚起され る可能性がある。

\section{4. 中山間地域再生事例の把握}

近年、日本の中山間地域の再生を実現する新たな取り 組みが現れている。その事例を本研究のフレームでとら え直してみると、地域に存在するストックを活かしてイ ンフロー・アウトフローを生み出すメカニズムの創生が 見てとれる。以下に例を挙げて説明する。

（1）福井県勝山市北谷町小原集落

小原集落は、明治期には 500 人超が居住していた。こ の頃の中山間地域では全国的に見られた傾向であるが、 林業とともに養虫が盛んであり、生糸の供給源となるこ とで、10 数 $\mathrm{km}$ 先の繊維業を地場産業とする勝山市街地 と共栄することができていた。しかしその後の䋊維業そ して養虫の衰退に加え、街と集落を結ぶ国道が開通した ことや、1960 年前後の豪雪の影響もあって、集落の若 者はこぞって街に移住していった。

小原集落の現在の人口は 3 人（実際の定住者は 2 人、 ともに 65 歳以上）である。人口だけから判断すれば集 落機能を維持することはもはや不可能なはずで、消滅を 待つだけの見向きもされない荒れた集落に思える。しか し現地の実態は、確かに耕作放棄地はあるものの人口 2
人とは思えないほどの農地が耕されている。森林もひど く荒廃しているわけではなく、むしろよく管理されてい ると言える状態にある。

小原集落にある主なストックは、半自然資本として、 斜面につくられた 1 枚あたりの面積が小さい農地（田・ 畑）のほか、管理された人工林と天然林（二次林）があ る。人工資本としては、森林につくられた林道、修復す れば居住可能な空き家 (福井県では珍しい白山麓文化の 影響がある建築物）が数軒、大正時代（1913 年）に建 てられた道場（御堂）などがある。これらのストックを 活かして、多くのフローを小原集落は生み出している。 例えば、天然林エリアには、インフローとしての登山客 が林道を歩き、アウトフローとしての QOL の享受の場と なっている。人工林では、インフローとしての森林組合 職員（地域外住民）の労働によって森林の維持管理が行 われ、アウトフローとして木材販売だけでない多面的機 能の発揮に寄与している。

このようなフローの維持が、ストックに影響を与え ることにもなった。2006 年より福井県内の大学と協㗢 して古民家の再生が行われ、そのうちの 1 軒は宿泊施設 というストックを生み出した。この宿泊施設は、体験型 農業や耕作放棄地復興作業などのグリーンツーリズムな どのアウトフローの増大に寄与している。また、農地に おいては勝山市内中心部および周辺地域からの交流人口 による家庭菜園なども行われており、農地の耕作放棄地 化の抑制にも貢献している。

このように、小原集落は定住人口 2 名であるにもか かわらず、交流人口は多く、それが支える森林・農地ス トックの十分な活用に伴うインフロー・アウトフローが 豊富にある。

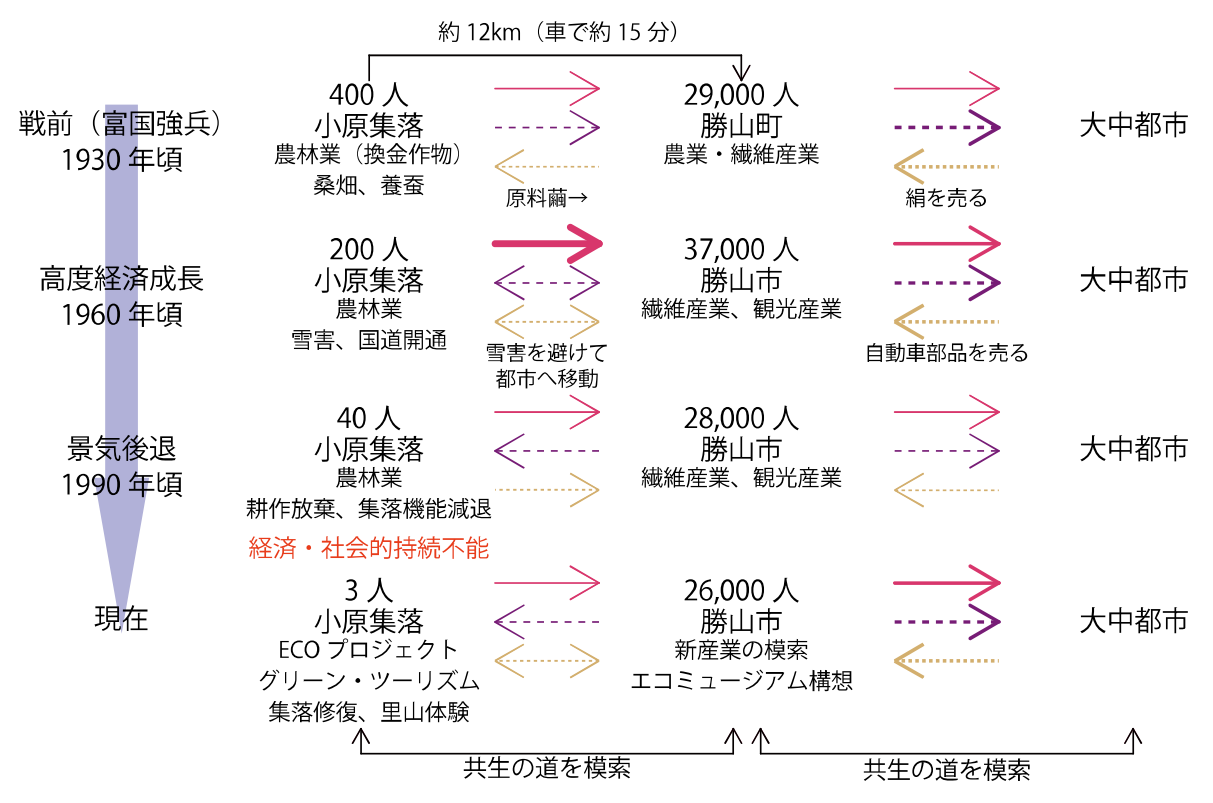

図-4 小原集落をめぐるストック・フロ一の変遷 
（2）愛知県豊田市足助地区新盛集落

足助地区（合併前の足助町）は、現在でも日本有数の 紅葉景勝地である香嵐渓を有する観光地として賑わいを 見せている。しかし、定住人口は下降を続け、1970 年 から始まる 4 次の過疎対策法にあって、一貫して過疎指 定を受けてきた地域である。足助町のうち町なかは観光 地化していったが、他の大部分は山間地であり、住民は 農林業を営んできた。

町なかから数 $\mathrm{km}$ 離れた新盛集落も、かつては農林業 を生業としていた地域の 1 つである。といっても、山に 囲まれた川沿いの狭い農地では自給自足農業を営んでい る農家が多く、高度経済成長以降の現金収入の必要性の 高まりとともに、次々に都市地域へ労働力が流出してい った。その背景には、20 数 $\mathrm{km}$ 先の豊田市街地にある自 動車産業による雇用吸収力が大きかったことは疑いない。 2009 年現在の人口は 168 人、高齢化率は $31.0 \%$ でる。

新盛集落における主なストックは、半自然資本として、 1 枚あたりの面積が小さく耕作放棄地も多い農地（田・ 畑）、管理が行き届いているとは言い難い森林（人工林、 天然林）がある。人工資本として、空き家が数軒ある。 半自然資本、人工資本ともに、多くの過疎地域に見られ るものと変わるものではない。しかし人的資本として、 定年を迎えたばかりの元気な 60 歳代の人が多く、彼ら が様々なフローを生み出す担い手となる。彼らは、耕作 放棄地という不良ストックの再生を、名古屋や豊田など に住む都市住民（インフロー）とともに始めた。都市住 民には、レクリエーション効果等の QOL 向上のほか、自 分で作った安全な米・野菜を持ち帰るというアウトフロ 一を生夕出し、耕作放棄地から農地へのストック再生を もたらした。これが農地の持つ多面的機能の回復に寄与 したことは言うまでもない。
彼らの次の狙いは定住促進である。都市住民が中山 間地域に出入りするフローから定住人口というストック を生み出すこと（いわゆる I ターン）は、容易なことで はない。中山間地域には地域ごとに大切にしている風 土・慣習があり、多くの場合、地域に「馴染む」プロセ スを必要とする。新盛集落では、耕作放棄地を市民農園 としてストック化することで、同じ人に何度も足を運ん でもらう機会を生み出すことで、地域に「馴染む」プロ セスを組み込もうとしている。今後定住希望者が現れた 時のための住居ストックの新設も計画されている。

\section{（3）新たなフローの構困}

以上の事例以外にも、中山間地域のストックが生み出 すフローとして、道の駅などでの農産品や林産品の加工 やブランド化などの知識・技術導入（インフロー）によ って生夕出される高付加価值産品（アウトフロー）販売 の取り組みや、「緑の雇用担い手育成対策事業」での林 業従事者の増加（インフロー、またその結果としてのス トック）によって森林が適切に管理されることにより生 み出される二酸化炭素排出権、なども考えられる。既存 フローおよび以上新たなフローをまとめると、図-6のよ うに表現され、中山間地域の評価をより広い視点から行 う必要があることが分かる。

これらの新規フローは、半自然資本から生み出される。 その維持・向上に努めることが、中山間地域において持 続可能なフローを生み出し得る。これは施策の上でも、 半自然資本の維持・向上に寄与寸るかどうかの視点を盛 り込む必要性を示す。今後強化すべき施策として、例え ば、表-2 のようなものが挙げられる。これらは、既存 資本強化（=既存フロー増加） と新規資本強化（新規フ ロー創出）の 2 つに分けて考えることができる。既存

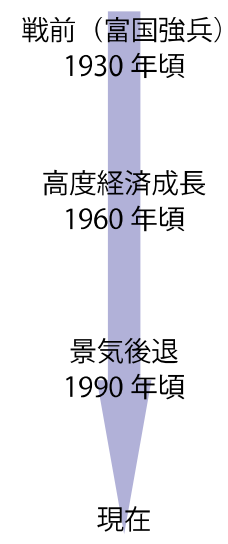

約 $24 \mathrm{~km}$ （車で約 40 分）

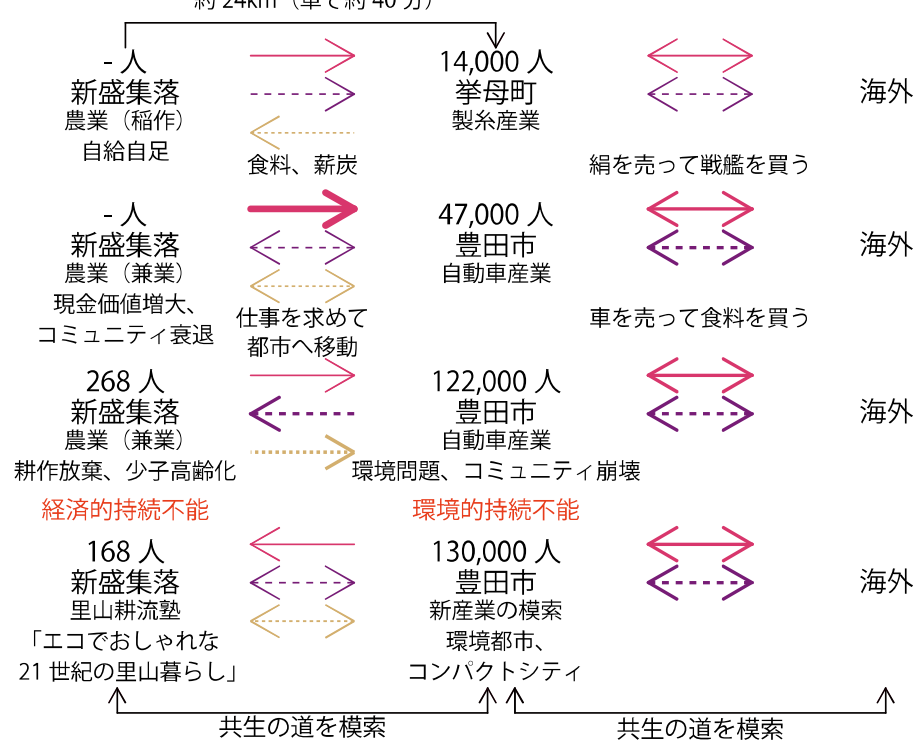

図-5 新盛集落をめぐるストック・フローの変遷 


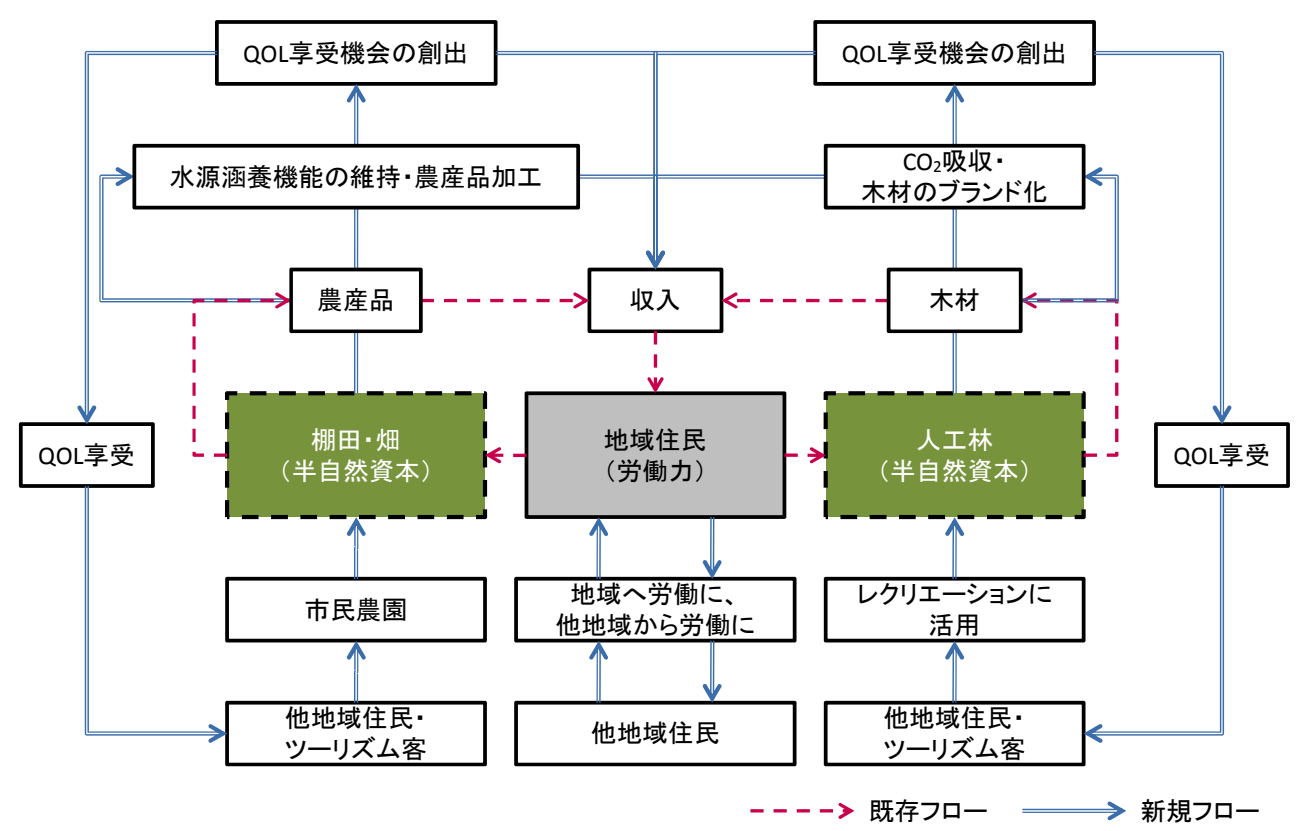

図-6 既存ストックの再評価と新規フロ一の可能性

表-2 半自然資本のフロ一創出能力顕在化施策

\begin{tabular}{|c|c|c|}
\hline \multirow[b]{2}{*}{ 森林 } & 既存資本強化 & $\begin{array}{l}\text { 林業従事者増加 } \\
\text { 木材のブランド化(SFC、SGEC などの制度) } \\
\text { 国内消費、地産地消化推進 }\end{array}$ \\
\hline & 新規資本強化 & $\begin{array}{l}\text { 適切な維持管理 }(\text { 間伐 })=\text { 多面的機能維持 }\left(\mathrm{CO}_{2} \text { の吸収源、水源 }\right. \\
\text { 涵養など) } \\
\text { 生物多様性への対応 } \\
\text { 質の高いツーリズム・ビジネス展開 }\end{array}$ \\
\hline \multirow[b]{2}{*}{ 農地 } & 既存資本強化 & 特産品の現地加エによる高付加価値化 \\
\hline & 新規資本強化 & $\begin{array}{l}\text { 棚田維持管理による水源涵養機能保全 } \\
\text { 農業体験等、観光事業(市民農園など)の活性化 }\end{array}$ \\
\hline
\end{tabular}

資本強化に関しては、森林を例にとると、3 章 3 節でも 述べたように、材のブランド化等を推し進めることで 国際的に認められた材を生産し新たな需要を起こすため に、一定の供給量の確保が求められる。一方で、そのた めには適切な人数の林業業従事者がいなければならない。 しかしこれが不足していることが大きな課題であり、従 事者の増加を強く推し進めるべきである。これを行うこ とにより多面的機能が維持され、付随して創出される新 規フローは中山間地域の住民に留まらず、都市地域の住 民にも資するアウトフローを生み出す。農地の維持管理 もこれと同様、多面的機能の一部を担うものである。

また、これら多面的機能一の正当な対価を、都市地 域からのインフローとして得られるように、多面的機能 の内部化メカニズムを仕組みとして整えることも必要で ある。さらに、管理された森林での登山および農地での 農業体験など、ツーリズム・ビジネスの展開、地域の特 産品の現地加工・現地販売による商品の高付加価值化な どの新規資本強化による活性化施策をとることで、交流 人口が増加し、地域での購買活動が増加することで中山
間地域住民の所得増加が見込まれる。これは人口減少の 歯止めとなる可能性もある。また、これらさまざまなフ ローの増加策が、結果的には森林・農地のストックにイ ンフローとして再投入され、半自然資本が持続可能な状 態として維持されることとなる。

\section{5. まとめ}

本研究では、日本の中山間地域が直面している現状を 分析するために、地域が有するストックとフローを把握 することで、その地域がどれだけの経済的価值およびQ0 Lを創出しているかを表現するフレームを作り上げた。

今後は、本研究で定性的にしか扱われていない各種ス トック・フロー要素の数值化を試み、定量的評価が可能 なシステムを検討する。そして、さまざまな中山間地域 における各種ストックの状況、特に、不良ストックを再 生できる可能性について検討し、それによって生み出さ れるフローと、その維持のために必要となる地域人口と の関係から規定される「地域の社会的必要性」を定量的 
に把握することによって、各集落の差異を分析するとと もに、どのような地域が将来的にも持続可能でありうる か、また、持続可能な状態に変えることができるかを検 討していく予定である。

\section{謝辞}

本研究は科研費（21057041）の助成を受けたものである。 ここに記して謝意を表する。

\section{参考文献}

1）国土交通省 : 国土形成計画策定のための集落の状況 に関する現況把握調査最終報告，2007. http://www. ml it. go. jp/kisha/kisha07/02/020817_.html

2）大野晃 : 山村環境社会学序説 現代山村の限界集落 化と流域共同管理，農山漁村文化協会，2005.

3) Partha Dasgupta : Human Wel1-Being and the Natural Environment, Oxford University Press,
2004.

4) Donella Meadows : Indicators and Information Systems for Sustainable Development, Sustainability Institute, 1998.

5）宇沢弘文 : 社会的共通資本，岩波新書，2000.

6 ）祖田修: 都市と農村の結合，大明堂，1997.

7 ）坂本慶一ほか：地域農業の革命, 明文書房, 1983.

8）日本学術会議 : 地球環境·人間生活にか力わる農業 及び森林の多面的な機能の評価について, 2001.

9) World Commission on Environment and Development : Our Common Future, Oxford University Press, 1987.

10）作野広和：農山村地域における低次中心地の衰退 過程一島根県川本町を例として一, 経済地理学年報, Vol. 41, pp. 155-170, 1995.

11 ）作野広和：島根県中谷集落における就業構造と集 落維持システム, 島根大学教育学部紀要 (人文・社 会科学)，Vol. 35, pp. 41-55, 2001.

\section{ストック・フロー構造の把握による中山間地域の持続可能性検討フレーム*}

宮田将門 $*^{2} \cdot$ 戸上昭司 $*^{3} \cdot$ 加藤博和 $*^{4} \cdot$ 川瀬康博 $*^{5} \cdot$ 林良嗣 $*^{6}$

日本の中山間地域は、都市地域からの支援なくして持続不可能である一方、急激な人口減少および少子高齢 化によってそれが困難である。地域の必要性・存在意義や維持発展のあり方を再検討し、新たな施策を実施す ることが必要となっている。このような中山間地域こついて、衰退過程および現状を捉える枠組みとして、地 域が有するストックとそれに伴い発生するインフロー・アウトフローとの関係を表現する方法を提案する。再 生を果たした中山間集落でフィールドワークを行い、ストック利用によるフローの変遷を把握することにより、 限界集落であってもストックを活かすことで、持続可能な状態になり得ることを示している。

\section{An Analysis Framework Applying “Stock-Flow Model” for Examination of Sustainability of Hilly and Mountainous Area*}

By Masato MIYATA ${ }^{*^{2}} \cdot$ Shoji TOGAMI* ${ }^{3} \cdot$ Hirokazu KATO $*^{4} \cdot$ Yasuhiro KAWASE $*^{5} \cdot$ Yoshitsugu HAYASHI $^{*^{6}}$

It is important to implement a new political reconsideration measures in the hilly and mountainous areas in Japan. This paper proposes a method that analyzes the stocks in mountainous area and relationships between general inflows and outflows. The study uses as a framework for evaluating decaying process and the overall existing situation. The actual situations show the achievability of "sustainable condition" by understanding the flow dependency of the stock usage. 